\title{
Geriatric teaching in Brazilian medical schools in 2013 and considerations regarding adjustment to demographic and epidemiological transition
}

\author{
ana Concelção Norbim Prado Cunha ${ }^{1}$, Natália Norbim Prado Cunha ${ }^{1}$, Maira Tonidandel Barbosa* \\ ${ }^{1}$ Medical student at the Universidade Federal de Minas Gerais (UFMG), Belo Horizonte, MG, Brazi \\ ${ }^{2}$ Associate Professor, Faculdade de Medicina da Universidade Federal de Minas Gerais and Faculdade de Ciências Médicas de Minas Gerais, Belo Horizonte, MG, Brazil
}

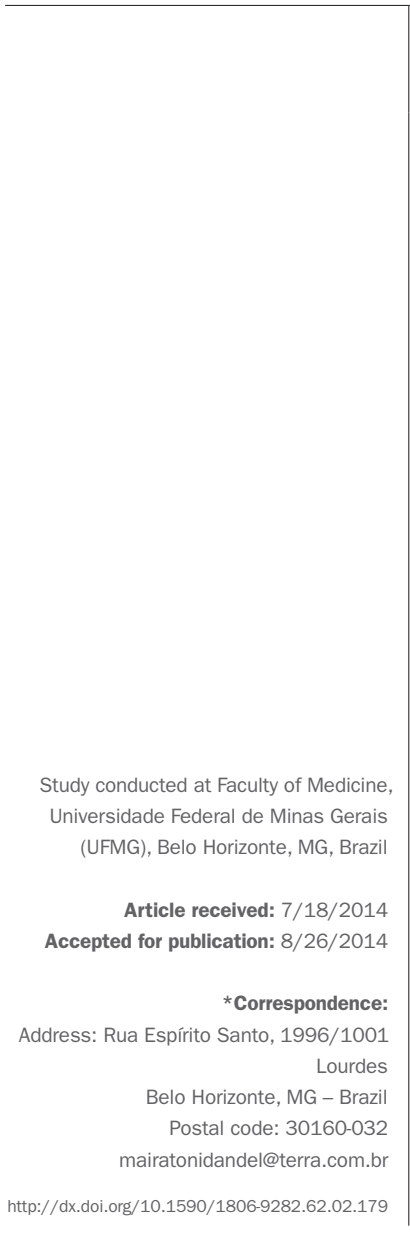

\section{SUMmaRY}

Objective: This study aims to describe the profile of medical schools that introduced courses on Geriatrics and Elderly Health or Aging in their curriculum, and compare such information with the age distribution and health epidemiological data of the Brazilian population, using data until the year of 2013.

Methods: 180 universities offering medical undergraduate courses and registered with the Ministry of Education and Culture of Brazil (MEC) were found, as seen on the MEC website (www.emec.mec.gov.br) in February 2013. Based on the list of institutions, the authors created a database.

Results: Brazil's Southeast region is the one presenting most of the courses, both offered as core or elective subjects, in the area of Geriatrics. The Midwest region had the least offer of Geriatrics and Elderly Health and Care courses. The Southeast region presents the greater absolute number of institutions with elective subjects, followed by the South and Northeast regions, each with a single institution. The Southeast region was at the same time the one that presented the biggest absolute number of institutions offering core subjects in the area of Geriatrics, being followed by the Northeast, South, North, and Midwest regions. Conclusion: By analyzing the availability of courses that emphasize aging and Geriatrics in brazilian medical schools, the present study reveals that specialized training should be encouraged with respect to the specificities of health care given to the elderly population, which has a higher frequency of chronic and degenerative diseases.

Keywords: Medical schools, demographic transition, epidemiological transition, geriatrics.

\section{INTRODUCTION}

The World Health Organization defines the elderly as anyone aged 60 or over. This definition may change according to location, so that the age of 60 years is adopted in developing countries, while 65 is used in developed countries. According to the Brazilian Census Bureau (IBGE), Brazil's population is aging fast. By 2039 , the country is expected to shift to a negative growth rate, which will result in decrease of the population and changes in the age structure. By 2050, the growth rate of the Brazilian population should fall -0,291, which represents 215.3 million people. According to information published by the IBGE, for every 100 children aged 0 to 14 years, there will be 172.7 elderly individuals in 2050 . The life expectancy of Brazilians increased from 45.5 years, in 1940, to 72.7 years, in 2008 . The forecast for 2050 , according to the IBGE, is 81.29 years. ${ }^{1}$

The rapid growth of the elderly population in Brazil raises the important question related to the capacity of society to adapt to this new reality. As the age of a person increases, there are biological, psychological and social changes that require differentiated care. Some of the topics discussed at the $2^{\text {nd }}$ World Assembly on Ageing of the United Nations (UN) were government, political, economic and cultural actions to ensure the effective participation of the elderly in the society. According to the study 
Socio-demographic and health indicators in Brazil (2009), ${ }^{2}$ the main urban centers do not have adequate infrastructure to meet the demands of a population with the current demographic profile. In recent decades, there has been a change of the epidemiological profile. Infectious diseases, responsible for about $40 \%$ of deaths in the 1950 s, represented a percentage of less than $10 \%$ in 2009 . On the other hand, there was an increase in chronic degenerative diseases, such as cardiovascular diseases, which in 2009 accounted for $40 \%$ of causes of death in Brazil. ${ }^{2}$ This transition relates to the characteristic profile of a population with increasing life expectancy, since chronic diseases grow considerably with increasing age. Also according to the study, chronic diseases affect $75.5 \%$ of the elderly. Thus, populations with higher percentages of elderly people have a higher rate of diseases, including neurodegenerative and disabling conditions. Thus, there is consequent higher demand for medical services. In 2003, according to the National Household Sample Survey (Pnad) conducted by the IBGE, ${ }^{3} 71.2 \%$ of elderly men and $83.4 \%$ of elderly women had at least one medical appointment at an interval of 12 months. It is in this context that the issue related to the training of doctors and other professionals, as well as health services required to take care of the elderly population is inserted.

When analyzing medical educational institutions in Brazil, specifically, it is important to highlight some fundamental aspects that influence such training to the new reality of health, which has been changing with an increased elderly population. These aspects include the impact of the curricular model in the training of future physicians, and the distribution of both teaching institutions and medical specialties throughout the country's territory, taking into account the demographic profile of each region and the different needs they have in order to provide health care. Law $n^{\circ} 8,842$, of January $4,1994,{ }^{4}$ states that Gerontology and Geriatrics courses must be included as curricular subjects in undergraduate courses. In the study Geriatrics education at Brazilian medical schools, ${ }^{5}$ it was found that in 2007, of a total of 167 institutions surveyed, only $42 \%$ included Geriatrics and other courses related to aging in their curricula. This study also states that the Southern region presented the greater proportional inclusion of the subject in the curriculum (69\%), followed surprisingly by the Northeast (46\%), North (38\%), Midwest $(36 \%)$ and Southeast (32\%) regions, noting that the latter has the highest number of elderly individuals in the country.

Data presented by the Federal Medical Board and the Brazilian Society of Geriatrics and Gerontology on the concentration of Geriatric medical residencies in 2013 point to a higher concentration of vacancies for this medical specialty in the Southeast and South, which are the regions with the greatest absolute number of medical teaching institutions offering programs to care for the elderly. ${ }^{5}$ The aim of this study was to outline the profile of medical schools that have introduced courses related to Geriatrics, health of the elderly or aging in their curricula as elective or core subjects, and compare this profile with the age distribution of the population using 2013 data.

\section{Methods}

180 universities offering medical undergraduate courses and registered with the Ministry of Education and Culture of Brazil (MEC) were found, as seen on the MEC website (www.emec.mec.gov.br) in February 2013. From the list of institutions found, a database containing geographic region and type of ownership (federal, state or municipal government, or private equity) of each was created. The authors searched electronically the curriculum of each school, which allowed them to analyze the presence of courses with emphasis on Geriatrics and aging process or health of the elderly. Whenever the information could not be found online at the school's website, the authors sent emails to the course coordinators requesting participation in the survey by sending the investigated data. A descriptive quantitative analysis of the number of medical schools that offer such courses and a qualitative comparison of these data with the current age and socio-demographic profile of the country were made.

\section{ResULTS}

180 Brazilian medical educational institutions registered in the MEC system were analyzed. Regarding the analysis of type of ownership, $5 \%$ were under special administration regime, $12.7 \%$ were owned by the state government, $23.3 \%$ owned by the federal government, $1.1 \%$ owned by a local government, and $57.2 \%$ were private.

The states that had a higher total concentration of medical schools were São Paulo with 19.4\%, Minas Gerais with $15.5 \%$ and Rio de Janeiro with $8.3 \%$. São Paulo was the state that had more state government-owned and private schools, while Minas Gerais presented a greater number of federal government-owned schools. Figure 1 shows how the surveyed medical schools are distributed using the following variables: "demographic area where the school is located" and "presence or absence of core and elective subjects in the Geriatrics field", as reported in the curriculum of each institution. According to the Figure 1, 
we can conclude that the Southeast region is the one presenting most of the courses, both offered as core or elective subjects, in the area of Geriatrics. The Midwest region had the least offer of Geriatrics and Elderly Health and Care courses.

In Figure 2, the surveyed medical schools are grouped according to the region they belong to and the offering of core and elective subjects in the Geriatrics field. It is clear that there is a higher concentration of medical schools surveyed in the Southeast. The graph allows the absolute number of medical schools that offer courses of care for the elderly to be compared. The Southeast region is the one with the greatest absolute number of subjects (in 27 medical schools), followed by the Northeast (17) and South (12) regions. The North and Midwest regions had, respectively, six and three medical schools with compulsory subjects, but none which offered elective cours- es in the area of care for the elderly. Some medical schools offered both options: core and elective subjects related to the topic of this study.

An important fact to emphasize is that a private college in the state of Minas Gerais sent us a note at the end of this study, with a curriculum that included, in addition to the core subject named Semiology in the Elderly in the third year of the program, a new internship in Health of the Elderly to start in January 2014, with total workload of 486 hours, not included in the results above. Courses similar to this internship in Health of the Elderly were not described in the curricula of the other medical schools surveyed.

\section{Discussion}

The current medical educational institutions can be divided into those adopting a curriculum based on the ep-

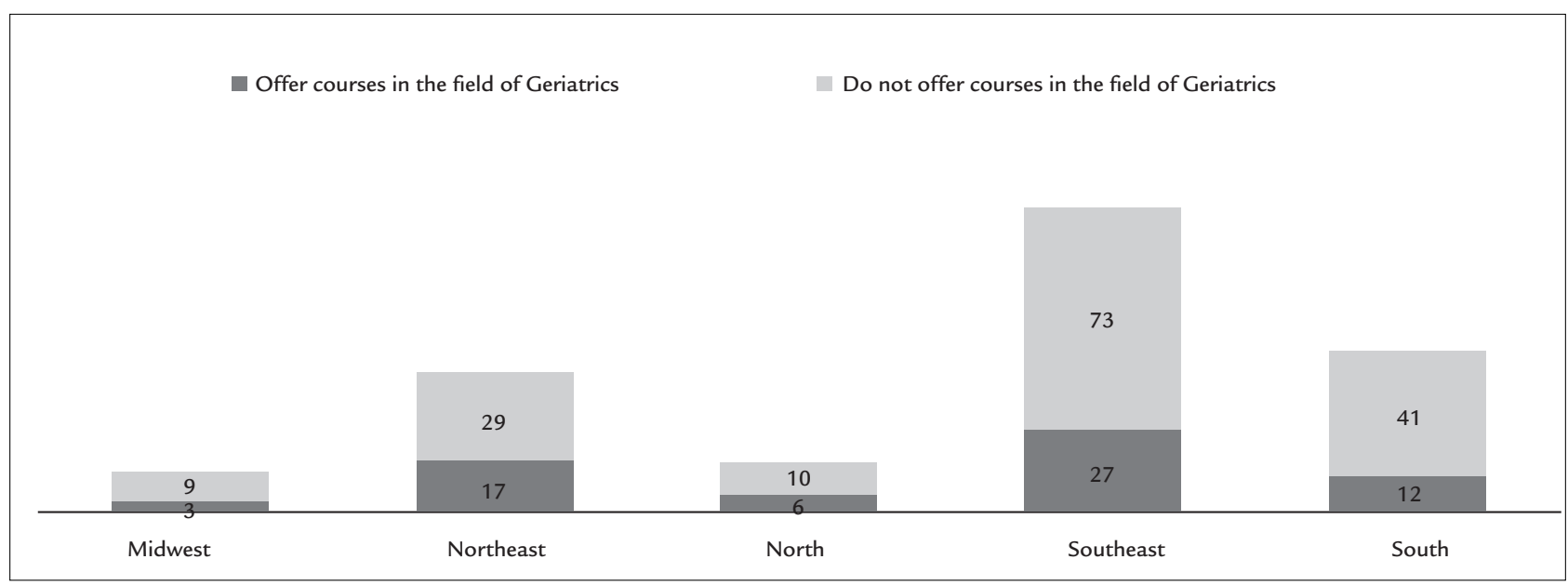

FIGURE 1 Absolute number of medical schools with elective or core subjects available in their curricula with an emphasis in elderly care.

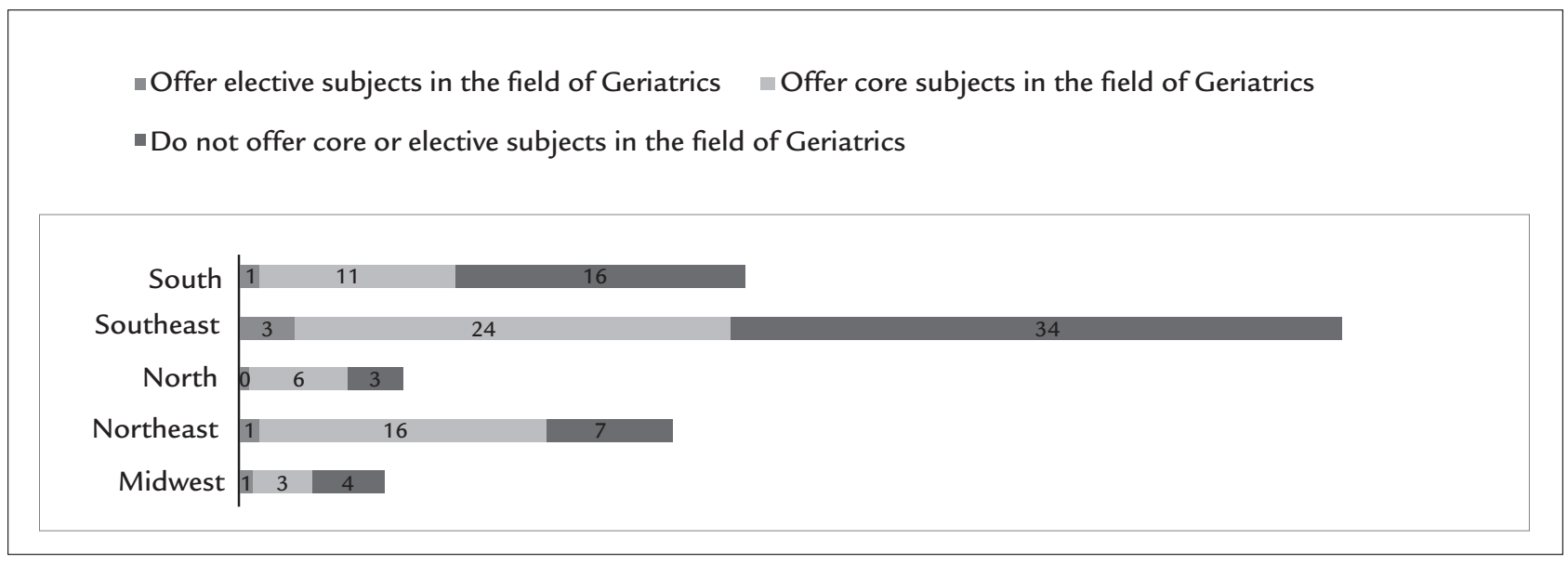

FIGURE 2 Offer of courses of elderly care in Brazilian Medical Educational Institutions. 
idemiological profile that focuses infectious diseases, those adopting a new curricular model suitable for the new reality of public health, and those currently undergoing a process of curriculum revision. The profile of the surveyed medical schools points to the prevalence of institutions in the Southeast and South regions, which is the most developed socioeconomic axis in Brazil today.

The Southeast and South regions are also the ones with the largest relative number of medical school offering elective or core subjects related to Geriatrics, aging or health of the elderly. The findings are in agreement with the Brazilian demographic profile. According to the demographic indicator of the proportion of elderly in the population (Ind010103), published by the Observatory on Inequities in Health of Fiocruz, ${ }^{7}$ based on the National Household Survey (Pnad), the macro-region with the highest proportion of people aged 60 or older in 2009 was the Southeast $(12.7 \%)$ region, followed by the South (12.3\%), Northeast (10.5\%), Midwest $(9.5 \%)$ and North (7.3\%). Throughout 2001-2009 there was an increase of approximately $25 \%$ in the proportion of elderly people, especially in the Southeast, and nearly $40 \%$ in the Midwest region.

The aging process is not the same in all individuals, so that while some may reach old age in good health, others - corresponding to a majority of individuals - develop chronic diseases. In Brazil, older adults are cared for by the Unified Health System (SUS) receiving an attention similar to that given to adults, only requiring more specific measures, usually complex in nature since primary care.

According to an IBGE study comparing 1960-2005 data, the striking fact in relation to chronic diseases is that they grow very significantly over the years: in the range $0-14$ years, only $9.3 \%$ of chronic illnesses were reported, while among the elderly this figure reaches $75.5 \%$ (69.3\% for men and $80.2 \%$ for women). According to the same study, older adults use more health services, are hospitalized more often and for longer periods, due to greater complexity and multiplicity of diseases, when compared to other age groups. Among the elderly, the per capita cost of hospitalization tends to increase as age increases, from BR\$ 93.00 per individual aged 60 to 69 years, to BR $\$ 179.00$ among those aged 80 years or older. In 2006, elderly men presented a lower per capita cost (BR\$ 100.00) than elderly women (BR\$135.00).

A major milestone in the context of elderly healthcare occurred with the signing by the Minister of Health in December 1999 of Ministerial Directive no 1,395, which established the National Policy on Health of the Elderly. Its primary purpose is to restore, maintain and promote the autonomy and independence of older adults, directing collective and individual health measures towards this end, in line with the principles and guidelines of the SUS. According to the guidelines set by this policy and in order to meet some requirements proposed by it (such as updated scientific knowledge regarding the health of the elderly and the need to pursue quality of care for older individuals through actions based in a paradigm of health promotion), we must incorporate the teaching of Geriatrics and courses involving knowledge of the aging process into medical educational institutions.

Wong and Carvalho ${ }^{6}$ show that the challenge posed by epidemiological transition for the elderly is related to the need to generate resources and build infrastructure to enable active aging.

The WHO defines active aging as the process of optimizing opportunities for health, participation and security in order to enhance quality of life as people age. In this sense, encouraging the incorporation of courses that include the process of aging and Geriatrics by medical schools can result in better trained health professionals to the new demographic and epidemiological reality of the country, therefore developing the concept of active aging.

In 1995, the WHO redefined its aging program and created the Aging and Health Program. The program's goal has been to develop policies that ensure "the achievement of best possible quality of life, for the longest possible time and to as many people as possible." For this to be achieved, the WHO encourages the promotion of knowledge in Gerontology and Geriatric Medicine through training and research activities. The organization also states that it is necessary to adopt interdisciplinary and intersectoral initiatives, especially those directed to developing countries facing rapid and unprecedented rates of population aging, within a context of prevailing poverty and unsolved infrastructure issues.

\section{Conclusion}

By analyzing the courses offered in Brazilian medical schools that emphasize aging and Geriatrics, this study shows that encouraging the training of health professionals with regard to the specificities of health care provided to the elderly population is essential. Thus, medical education should follow the profile of the current demographic and epidemiological transition, training professionals who will be better able to encourage active aging and to dodge possible existing infrastructure failures.

The WHO emphasizes the goals of prolonging the years of healthy life, reducing health disparities between different population groups and ensuring access to pre- 
ventive health services. These objectives are directly related to the current need of reformulation of public policies for the adequacy of health care to an aging population. ${ }^{8}$ Priorities include curriculum changes in most medical educational institutions, which should adopt a model of education more appropriate to the needs of an epidemiological profile more marked by chronic diseases than by infectious diseases, as well as an aging population increasingly prominent in contrast to the declines in current birth rates.

Curricular adjustments and adaptations are needed to include topics on nosologies that are increasingly frequent due to population aging, such as cardiovascular and cerebrovascular diseases, osteoarticular, hematological and oncological conditions, neurodegenerative diseases, chronic kidney disease, and also complications and disabilities related to prevalent chronic diseases, such as diabetes. Increasingly, these conditions require management of multiple diseases and other environmental and psychosocial aspects of the elderly by trained health professionals, who are able to see and approach these patients broadly, at all levels of care, from primary care to much more complex tertiary outpatient and hospital activities. The care for the elderly should be multidisciplinary and interdisciplinary, with adequate technical division of labor, according to the chronic conditions presented by each patient, preserving the unity of treatment plans made by professionals with more knowledge of Geriatrics, in an integrated communication process, in order to avoid the fragmented care system. We believe that all of these topics should be included in the teaching and training practices offered by medical schools, as courses related to aging and health of the elderly.

\section{Resumo}

Ensino da Geriatria nas faculdades de medicina do Brasil em 2013 e reflexões sobre a adaptação ao processo de transição demográfica e epidemiológica

Objetivo: o estudo tem como objetivo delinear o perfil de instituições de ensino médico que adotaram em grade curricular disciplinas de Geriatria, saúde dos idosos ou envelhecimento, e comparar esse perfil com distribui- ção demográfica e dados epidemiológicos de saúde da população brasileira, utilizando dados de até 2013.

Métodos: foram pesquisadas 180 instituições de ensino superior (IES) contendo cursos de medicina cadastrados no sistema do Ministério da Educação e Cultura (MEC), que constavam no site: emec.mec.gov.br, acessado em fevereiro de 2013. A partir da lista de instituições encontradas, fez-se a construção do banco de dados.

Resultados: a região Sudeste é a que apresenta maior oferta de disciplinas na área de Geriatria, tanto obrigatórias quanto optativas. A região Centro-oeste foi a que menos se destacou na oferta de disciplinas de cuidado ao idoso. A região Sudeste apresenta maior número absoluto de disciplinas optativas, seguida pelas regiões Sul e Nordeste, com apenas uma instituição cada. A região Sudeste também foi a que apresentou maior número absoluto de instituições que ofertavam disciplinas obrigatórias na área de Geriatria, sendo seguida pelas regiões Nordeste, Sul, Norte e Centro-oeste.

Conclusão: o presente estudo, por meio da análise do perfil de oferta de disciplinas que enfatizam o envelhecimento e a saúde do idoso nas instituições de ensino médico brasileiras, aponta como essencial o estímulo à capacitação dos profissionais no que tange às especificidades do atendimento de saúde à população idosa, com aumento crescente de doenças crônico-degenerativas.

Palavras-chave: escolas médicas, transição demográfica, transição epidemiológica, geriatria.

\section{References}

1. Instituto Brasileiro de Geografia e Estatística. Estatísticas da saúde: assistência médico-sanitária. [cited 2013 apr 10]. Available at: http://www.ibge.gov.br.

2. Instituto Brasileiro de Geografia e Estatística. Estatísticas da saúde: assistência médico-sanitária. [cited 2013 apr 10]. Available at: http://www.ibge.gov.br/ home/estatistica/populacao/indic_sociosaude/2009/.

3. Instituto Brasileiro de Geografia e Estatística. Estatísticas da saúde: assistência médico-sanitária. [cited 2013 apr 10]. Available at: http://www.ibge.gov.br/ home/estatistica/pesquisas/pesquisa.

4. Empresa de Tecnologia e Informações da Previdência Social. [cited 2013 apr 10]. Available at: http://www010.dataprev.gov.br/sislex/paginas/42/1994/8842.htm.

5. Pereira AMVB, Feliz MC, Schawanke CHA. Ensino de Geriatria nas faculdades de Medicina brasileiras. Rev Geriatr Gerontol. 2010; 4(4):179-85.

6. Portal da Conferência Mundial de Determinantes da Saúde. [cited 2013 apr 10]. Available at: http://dssbr.org/site/wp-content/uploads/2012/03/ Ind010103-20120130.pdf.

7. Wong LLR, Carvalho JA. O rápido processo de envelhecimento populacional do Brasil. Rev Bras Estud Popul. 2006; 23(1):5-26.

8. Relatório Mundial de Saúde 2008 da Organização Mundial de Saúde. [cited 2013 apr 10]. Available at: http://www.who.int/whr/2008/whr08_pr.pdf. 